\title{
Designing Storylines for Children's Mathematics Digital Interactive Storybook using Software Engineering Approach
}

\author{
Nurhamizah Zainudin $^{1}$, Azniah Ismail $^{2}$ \\ ${ }^{I}$ Faculty of Art, Computing \& Creative Industry, UPSI; nurhamizahzainudin97@gmail.com \\ ${ }^{2}$ Faculty of Art, Computing \& Creative Industry, UPSI; azniah@fskik.upsi.edu.my
}

DOI: https://doi.org/10.37134/jictie.vol7.1.5.2020

\begin{abstract}
This paper presents an early part of designing process for a math interactive storybook application prototype with 3D pop-up and augmented reality features. This application is designed using the evolutionary prototype model where we are required to have several complete 4-phases prototype model cycles. Several iterations were conducted specially to focus on getting the best storylines for a mathematics learning tool that involves $3 \mathrm{D}$ pop-up and augmented reality features. The process is still on-going. We will also validate with experts the storyline and the suitability of the story with the mathematic topics chosen. Once the design is validated, we will continue building the prototype and validate it with potential users until all features are satisfied. It is hoped that later this application will be accepted as an interesting learning tool and contribute as an educational learning resource for children.
\end{abstract}

Keywords: interactive storybook application, mathematics, storylines.

\section{INTRODUCTION}

Storytelling can become an interesting method in educating our children. Today, we can find many digital stories in form of e-book, videos, and applications available online. Some of them are free. Realizing that stories can have good impact on readers stories, some researchers started to focus on creating stories that can helps children or students learning and understanding subjects they learn at schools (Lemonidis \& Kaiafa, 2019; McGrath, 2014; Ayop, 2012; Griffith, 2007).

Mathematics is one of the subjects that can make use of stories (MathsThroughStories.org, 2017). It is one of the subjects that is considered tough among children and students. The problems were usually associated to misunderstanding or weak understanding of the concepts (Rojahan, 2004). The effects can be huge and most probably causing the declining numbers of students taking science stream in Malaysia (Phang et al., 2014). 
If all concepts in mathematics can be introduced through stories, children or students shall be able to visualize the concepts and might probably help them understand the concepts better and perhaps easier (Lemonidis \& Kaiafa, 2019). According to Palani Samy (2006), using any ICT-based applications can helps promote effective learning in Science and Mathematics subjects among students. Therefore, creating a well-designed tool specifically for Mathematics that able to let children visualize the concepts through stories might be useful. The stories might also help children in improving their reading skills similar to some applications suggested by Miswan and Adnan (2014) and Ayop (2012). Our research aims to develop a mathematics digital interactive storybook application for children aged seven to eight years old. In this paper, we present the first part of our research progress that focuses on designing suitable storylines for our storybook application. An interesting part that can be found in this paper is that we use software engineering approach to complete the job.

\section{METHODOLOGY FOR DESIGNING THE STORYLINES}

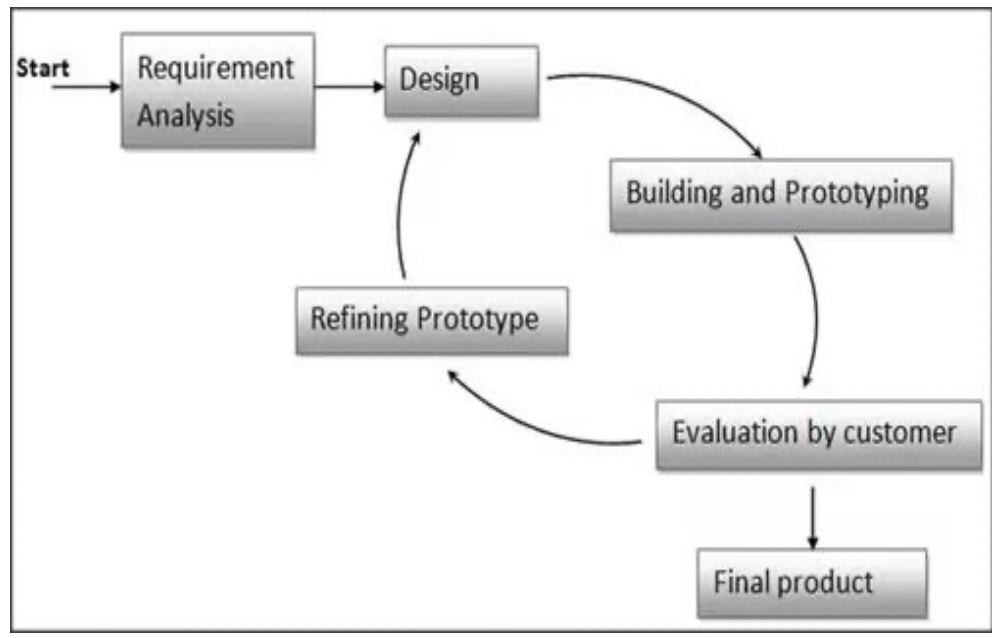

Figure 1: Evolutionary Prototype Model

In general, the research methodology is based on product development. Normally, ADDIE model is very popular as product lifecycle model for developing multimedia based products such as digital storybooks, videos, animation videos and etc. However, we choose the evolutionary prototype as our product development lifecycle model instead (see Figure 1). Based on this model, the prototype will be refined in several cycles starting from initial storyline draft, improved storyline draft, drawing sketches, and so forth. More interestingly, each output in each cycle will be evaluated before we can proceed to the next cycle. In prior to these cycles, we must conduct requirement analysis. 
In our case, we analyse qualitative data from existing storybook applications especially to identify suitable criteria of the storyline and criteria of the entirety of the product.

In general, our research activities during designing the storylines for our product are comprised of three main phases: (i) requirements elicitation to get storyline requirements, (ii) storyline planning, and (iii) storyline drafting (see Figure 2). Several cycles can be found during the third phase i.e. the storyline drafting, in which, evaluation happen at every cycle.

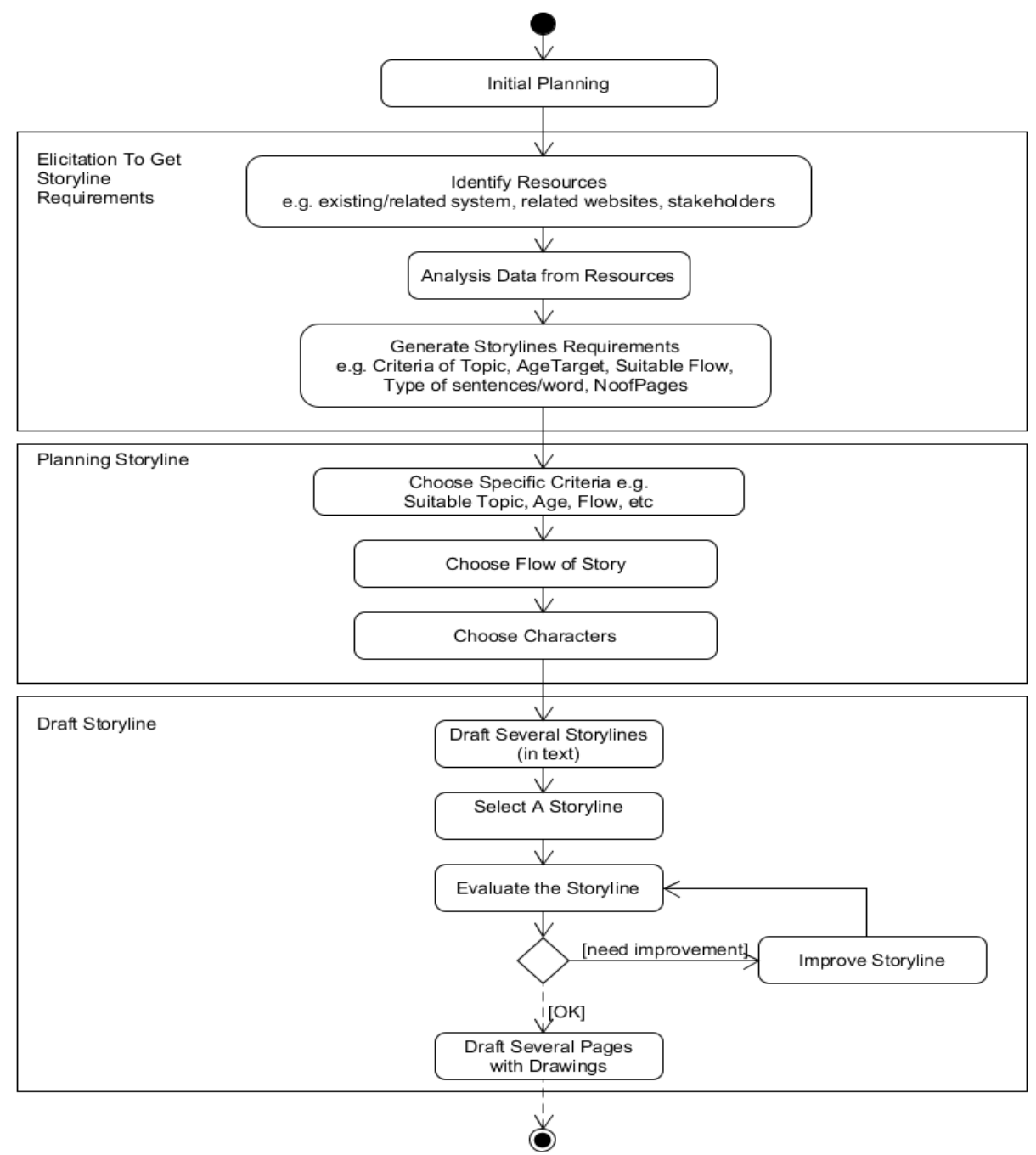

Figure 2: Research activities in designing the storylines. 


\section{i) Requirements Elicitation (to get storyline requirements)}

The initial requirements were collected using content analysis technique of existing storybook applications. The main objective is to investigate which features that should be considered for a storybook application.

\section{ii) Planning the storylines}

To help us to focus on the designing the storylines, we decided to choose specific criteria for the storyline such as topic, children age target, flow of the story, type of sentences or words, language, maximum number of storybook, situation and characters in the story.

\section{iii) Draft the storylines}

The First Cycle: Initial Design of Storylines:

a) Quick Design

We selected the concept of fraction and discussed the storyline.

b) Build Prototype (the storylines)

We built three different storylines.

c) Evaluate

For evaluation in this first cycle, we asked a computer science lecturer that also has a degree in mathematics to give us some initial comments on the storylines and the suitability of our storylines with the fraction concept.

d) Refine Requirements

We changed the storyline according to the comments which involved some parts of the situations and characters.

The Second Cycle: Design of Storylines:

a) Quick Design

Design was built based on the comments we got previously. We confirmed the concept of fraction in the design.

b) Build Prototype

We have three improved storylines. 
c) Evaluate

For this time, we asked a mathematics teacher in one of schools in Malacca to evaluate the suitability of our storylines with the fraction concept. We also asked this evaluator to check the concept explanation, suitability use of sentences and also words.

\section{d) Refine Requirements}

We improved the storylines according to the comments which involved omitting some parts of sentences to make them simpler. The teacher also suggests some drawing ideas that can support the fraction concept explanation.

Once the storylines are evaluated, the process will continue to iterate through several more cycles where we will continue building the prototype and evaluate it with potential users until all features are satisfied to be considered as the final product.

\section{FINDINGS AND DISCUSSION}

\section{Storyline Requirements}

Content analysis of existing or related storybook applications freely available. See Table 1.

Table 1: Content analysis findings on existing related applications.

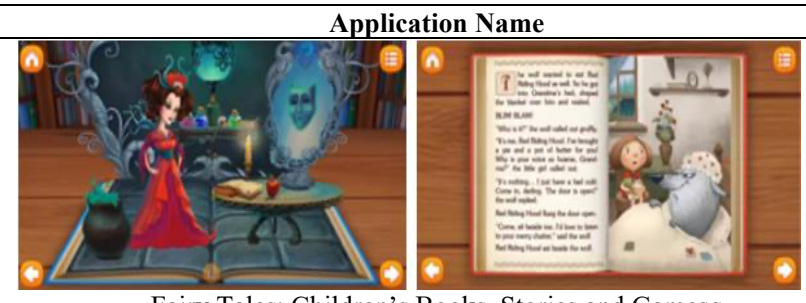

Fairy Tales: Children's Books, Stories and Gamesq

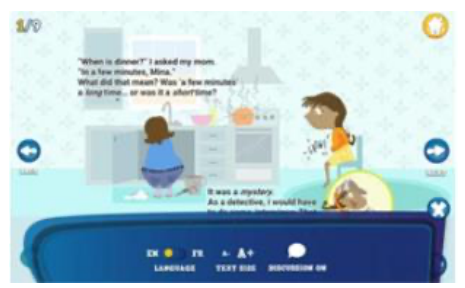

Math Storytime

Scope

Fairy tales (not related to mathematics)

Simple mathematics concepts such as time, length General Comments Each story has three magnificent 3D pop-up games in the middle of the story that might be able to attract the reader to keep on reading. Readers need to collect or buy points to get other stories in their collection.

Interactive animation, nice illustration 
Designing Storylines for Children's Mathematics Digital Interactive Storybook using Software Engineering Approach Received Date: 31 November 2019; Accepted Date: 05 January 2020
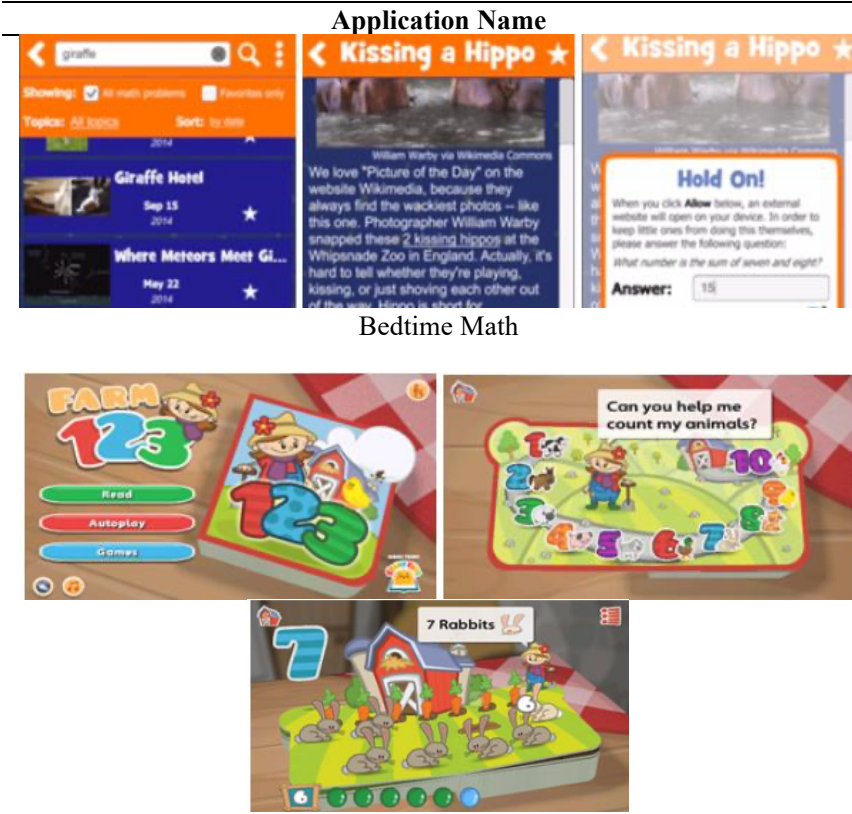

Farm 123 - Learn to Count!
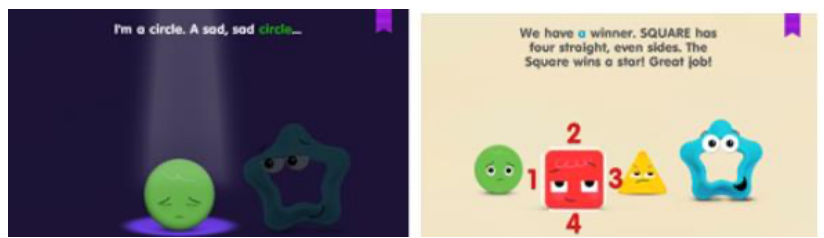

Tiggly Shape's Got Talent

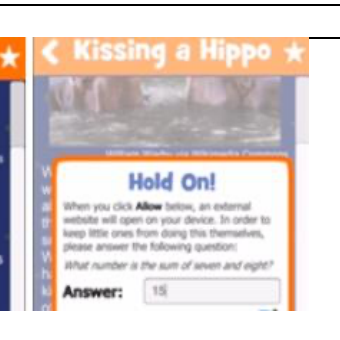

Scope

Simple

calculation

General Comments

Mostly about one-page descriptions not a story.

Less interesting

interface.

Counting

Augmented reality features. No specific storylines.
Geometry Nice simple story. Very

limited geometrical shapes. Interactive features.

\section{Storyline Plan}

Figure 3 shows the criteria that we decided on and must be followed in order to design the storylines.

Specific Storyline Criteria

Topic: Fraction

Age Target: 7-8

Flow: Straightforward, concept explained literally

Language: Malay

Type: simple words, short sentences, avoid ambiguity

Max. No of pages: Not more than 12

Characters: A cat family (cute Malaysian names for the kitties such as Bulat, Tompok, Comot).

Situation: Pick a situation where concept can be applied.

Figure 3: Specific Criteria for the Storylines. 


\section{Storylines Drafts}

Figure 4 and Figure 5 show the storylines improved during the first cycle. Figure 4 shows an example of a (part of) storyline drafted during the first cycle, and Figure 5 shows an example of storyline improved after the first cycle. The storylines keep improving after the second cycle and we are satisfied with the output from this storyline design process.

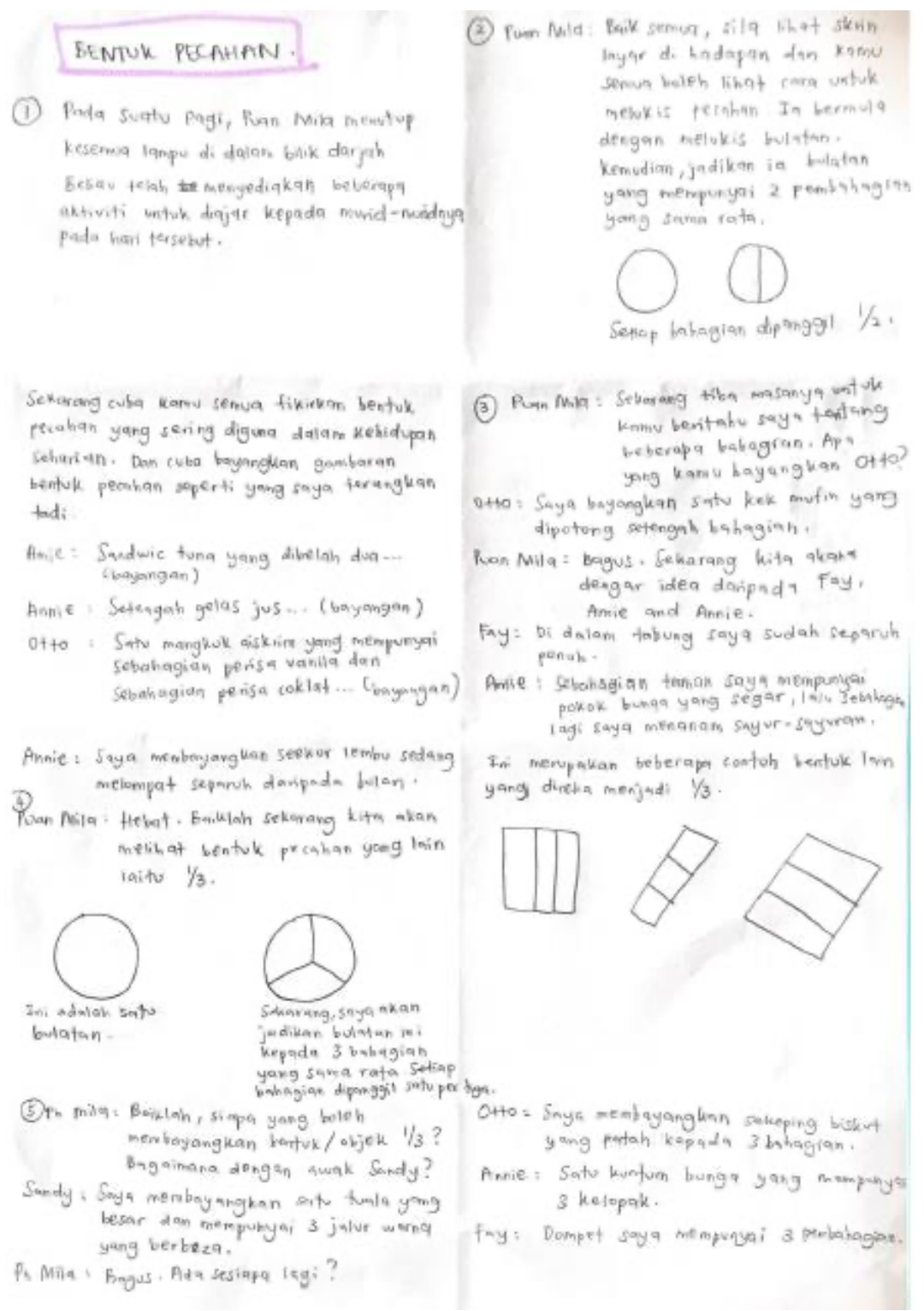

Figure 4: Part of storylines drafted during the first cycle. 
Designing Storylines for Children's Mathematics Digital Interactive Storybook using Software Engineering Approach

Received Date: 31 November 2019; Accepted Date: 05 January 2020

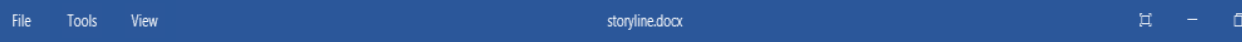

"MARI IBU AJARKAN PECAHAN"

Di dalam sebuah kampung tinggal sebuah keluarga kucing yang hidup aman dan harmoni. la terdiri daripada ibu kucing, bapa kucing dan

5 ekor anak kucing iaitu Belang, Tompok, Comot, Bulat dan Putih. Pada suatu malam sedang mereka berkumpul di ruang tamu, anak

kucing berceritakan tentang topik pelajaran yang telah dipelajari di sekolah kepada ibunya.

Belang : Ibu hari ini kami ada pelajari topik pecahan dalam matematik di sekolah. Tetapi topik kami tak fahamlah topik tersebut. Boleh tak kalau ibu ajarkan kepada kami tentang konsep pecahan?

Ibu kucing : Oh, topik pecahan. Sebenarnya topik itu mudah sahaja, pecahan ini selalu kita aplikasikan di dalam aktiviti seharian kita. Cuma kamu sahaja tidak perasan.

Bulat : Benarkah ibu? Kenapa kami tidak tahu sebelum ini?

Ibu kucing : Itu kerana kamu masih belum nampak dan pelajarinya. Sekarang setelah kamupelajari dan faham konsepnya mesti kamu akan sentiasa aplikasikan dalam kehidupan seharian kamu. Baiklah mari semua ikut ibu ke dapur, ibu ada membuat piza.

Anak-anak kucing: (muka teruja)

\section{CONCLUSION}

Stories may help readers to visualize and learn new things. Teaching mathematics through stories is an interesting method. We decided to develop such stories for children in form of interactive storybook but quickly realized the storylines are the main important part that will affect the readers. So, we make sure that the storyline designs will go through several cycles of the prototype process, evaluated by some experts in each cycle. Thus, we chose the evolutionary prototype model for our product development lifecycle. In prior to the storyline design process, we had also reviewed several existing storybook applications, mostly related to mathematics to make sure we consider all must-have functions for our interactive storybook application. In conclusion, based on our experience using the evolutionary prototype model to design storylines, the model is also suitable for multimedia-based product lifecycle that offers the benefit of doing evaluation in many cycles. 


\section{REFERENCES}

Ayop, N.W. (2012). Pembangunan Aplikasi Buku Cerita Interaktif Bercirikan Islam Untuk Platform iOS (iKids Stories). Master's thesis. Universiti Teknologi Malaysia.

Griffith, N. (2007). Stories can be counted on: Ideas for developing mathematics through story. UK: Red Robin Books.

Lemonidis, C., \& Kaiafa, I. (2019). The effect of using storytelling strategy on students' performance in fractions. Journal of Education and Learning, 8(2), 165-175.

MathsThroughStories.org. (Mar 2017). 'How to' books, University of Reading's Institute of Education (UK). Retrieved 10 May 2019, from https://www.mathsthroughstories.org/how-to-books.html

McGrath, C. (2014). Teaching Mathematics Through Story: A Creative Approach for The Early Years. Oxon: Routledge

Miswan, M., \& Adnan, H.M. (2014). Pembangunan Aplikasi Peranti Mudah Alih Untuk Kemahiran Membaca Kanak-Kanak: Aplikasi Literasi LINUS (LILIN). Malaysian Journal of Media Studies, 17(2), 64-78.

Palani Samy, P.M. (2006). Pelaksanaan Dasar Pengajaran Sains dan Matematik dalam Bahasa Inggeris di Sekolah-Sekolah Felda, Negeri Sembilan. Master's thesis. Universiti Malaya.

Phang, F.A., Abu, M.S., Ali, M.B., \& Salleh, S. (2014). Faktor Penyumbang Kepada Kemerosotan Penyertaan Pelajar Dalam Aliran Sains: Satu Analisis Sorotan Tesis. Sains Humanika, 2(4), 63-71.

Rojahan $\mathrm{Hj}$. Abdullah (2004). Pencapaian dan Kesalahan Konsep dalam Kerja, Tenaga dan Kuasa di Kalangan Pelajar Tingkatan Lima Aliran Teknikal. Master's thesis. Universiti Malaya. 